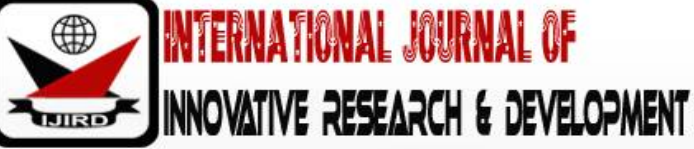

ISSN 2278 - 0211 (Online)

\section{The Moderating Role of Leadership Style on the Relationship Between Job Stress, Emotional Intelligence and Deviant Workplace Behavior}

\author{
Hari Sugiharto \\ Accountant, Department of Accounting, Islamic University of Indonesia, Yogyakarta, Indonesia
}

\begin{abstract}
:
Leadership style, work stress, and emotional intelligence are important variables that influence employee behavior including deviant workplace behavior that can affect organizational performance. This study investigates the effect of work stress, and emotional intelligence on deviant behavior in the workplace, and the moderating role of leadership style in the two relationships. Using multiple regression analysis and moderation regression analysis, this study involved 124 employees from KPP Pratama Magelang, Temanggung, and Klaten who served as Account Representatives. The results show that work stress has a significant positive effect on deviant behavior in the workplace, and emotional intelligence has a significant negative effect on deviant behavior in the workplace. Meanwhile the leadership style moderates the relationship between work stress and deviant behavior in the workplace, and moderates the relationship between emotional intelligence and deviant behavior in the workplace. The contribution of this study is to the managerial policy scenario and the development of employee competency standards. The paper concludes with a discussion of the results and implications for academics and managers.
\end{abstract}

Keywords: Leadership style, job stress, emotional intelligence, deviant behavior

\section{Introduction}

The success of an organization is largely determined by the performance of each employee. The performance achieved by each employee depends on how the employee concerned uses the competencies he has. In the field of work, these competencies are often associated with intellectual intelligence (IQ). But nowadays other types of intelligence appear that have an important role in one's success in maximizing their competencies, namely emotional intelligence (EQ). Goleman (2009) mentions the influence of IQ is only $20 \%$, while $80 \%$ is influenced by other factors including EQ. Thus, IQ can be said to be not dominant anymore in explaining or influencing someone's success. High emotional intelligence allows a person to be able to recognize his feelings well, motivate him, empathize with what others feel and ultimately lead the person to be able to manage relationships with others to achieve organizational goals. Job stress is a common problem faced by employees whose impact can extend to the organization. In addition to the negative consequences for an employee, work stress can also adversely affect the smooth functioning and operations of an organization. Absence and turnover are behaviors caused by work stress (Gupta \& Beehr, 1979). One prominent variable as a direct and indirect result of work stress is deviant behavior (Golparvar et al., 2012). Existing empirical research provides many findings showing that work stress is associated with negative behaviors such as deviant and counterproductive behavior (Lambert et al, 2007).

Deviant behavior is behavior in the workplace that goes beyond the construction of organizational norms and is carried out intentionally (Appelbaum et al., 2007). Nevertheless Appelbaum et al., (2007) states that deviations can be negative and positive. Negative or implicit negative deviations have negative consequences for the entity and its affiliates. Estimates of the impact of widespread theft by employees of the US economy have been reported to be worth $\$ 50$ billion per year (Appelbaum et al., 2007). Positive deviant behavior can consist of behavior that is not authorized by the organization, but helps the organization achieve its financial and economic goals. Thus, positive deviant behavior can include behaviors such as innovative behavior, non-compliance with dysfunctional directions, and criticizing incompetent superiors (Galperin, 2002). The movement of an organization is largely determined by a leader. The basic task of a leader is to move the team's emotions in the right direction (Goleman et al., 2004). So even though everything has been prepared correctly, but if the leader fails to carry out the basic tasks, what they do will not get the results properly (Goleman et al., 2004). Different leadership styles have different influences on employee behavior. For example, Hater and Bass (1988) found that transformational leadership has a stronger relationship with subordinate effectiveness and satisfaction than transactional leadership. In addition, when psychological empowerment is high, transformational leadership is positively related to innovative behavior, while transactional leadership has a negative relationship with innovative behavior (Pieterse et al., 2010). 


\section{Literature Review}

\subsection{Deviant Workplace Behavior (DWB)}

Research on deviant workplace behavior has been carried out using different terms (Alias et al., 2013). Douglas \& Martinko (2001) use the terminology of workplace aggression to examine the relationship between individual differences and the incidence of aggression in the workplace. Fox et al., (2001) use the term counterproductive work behavior in examining its response to work stress and organizational justice. Robinson \& O'Leary-Kelly (1998) use the term anti-social behavior in examining how these behaviors are formed by the social behavior of coworkers. In an effort to develop a conceptual framework in a comprehensive theory of work motivation, Vardi and Wiener (1996) introduced the terminology of organizational misbehaviour.

Workplace is an area or forum where different behaviors of each employee are expressed with different consequences for each individual in the organization and ultimately for the entire organization (Appelbaum et al., 2007). Different behaviors of each employee at the same time are influenced by norms, both individual norms and organizational norms. Norms exist in an organization and will regulate how members behave, think, make judgments and view the world (Stamper et al., 2000). Individual work behaviors that go beyond organizational norms have an impact on organizations at every level including in the decision-making process, productivity, and financial costs (Coccia, in Appelbaum et al., 2007). Robinson \& Bennett (1995) define employee deviant behavior as voluntary behavior that significantly violates organizational norms and can therefore threaten the welfare of the organization, its members or both.

Deviant workplace behavior is classified into two groups: positive and negative deviant behavior (Appelbaum et al., 2007). A behavior in the workplace is said to be deviant when the behavior exceeds the construction of organizational norms and is done intentionally. Furthermore, it is called positive deviant behavior when the goals of the behavior are respected (Spreitzer \& Sonenshein, 2004). Conversely, negative deviant behavior involves harassment, sabotage of equipment and other types of negative behavior that bring adverse consequences to the organization, its members or both. Robinson and Bennett (1995) developed a typology of deviant workplace behavior by using two dimensions to measure the nature of deviations namely minor versus serious and interpersonal versus organizational. Based on these two dimensions, his research produced four deviant behavior quadrants consisting of production deviations, property deviations, political deviance, and personal aggression.

Alias et al. (2013) concluded that there are three potential groups that determine deviant behavior in the workplace, namely factors related to individuals, factors related to organizations, and work-related factors. Factors related to individuals include negative effectiveness, awareness, level of agreement, and emotional intelligence. Factors related to the organization include the organizational ethics climate, unfair treatment, trust and support from low organizations. Meanwhile factors related to work include work stress and work autonomy (Alias et al., 2013).

\subsection{Job Stress}

Gibson et al., (2012, p. 195) define stress as an adaptive response, mediated by individual differences and / or psychological processes, which are consequences of any external action (environment), situation or event that places psychological demands and/or excessive physicality in someone. Based on this definition Luthans (2011, p. 279) emphasizes three important components that need to be considered: 1) stress refers to a reaction to a situation or event, not a situation or event itself; 2) stress can be influenced by individual differences; and 3) stress is a response to excessive psychological and / or physical demands because only special and unusual situations (as opposed to mild life adjustments) can really be said to cause stress. From this definition it can be said that stress varies for each person even if faced with the same situation or environment. A person who believes that his or her environment is unfriendly or dangerous, and who generally feels unable, is far more likely to feel threatened and react with anxiety than people who have high trust in available resources, or who believe that there are no problems with the environment (Lazarus Launier, 1978).

At different levels, Kahn \& Quinn (in Gupta \& Beehr, 1979) define work stress as a demand for every aspect of a job's role that has extreme or dangerous character. This extreme or danger is to distinguish stress from other work characteristics which only produce mild effects such as job dissatisfaction. Examples of work stress are such as role ambiguity, role conflict, role overlap, etc. (Gupta \& Beehr, 1979).

Stress does not necessarily have a negative effect on the performance of individuals or organizations. It is generally recognized that low stress levels can improve performance (Luthans, 2011, p. 294). Some of the effects of stress, of course, are positive, as are those that can motivate themselves and become stimulants to achieve individual goals and objectives (Gibson et al., 2012, p. 202). Associated with the impact of negative stress Gibson et al., (2012, p. 202-207) divided the impact of stress into 3 categories, namely behavior, cognitive, and physiology. The impact on individual behavior can be realized in the form of satisfaction, performance, absence, turnover, workplace accidents due to negligence, alcohol and drug abuse, temperamental, and increasing health care claims. Some of the effects of stress may be cognitive, such as the inability to make good decisions, lack of concentration, forgetfulness, frustration and apathy. Whereas the physiological effects include the increase in heart rate, high blood pressure, sweating, cold body heat, increased blood sugar levels, and increased production of stomach acid.

The response of each individual to a stress stimulus varies depending on the individual's ability to adapt to stress. Thus, the impact caused also varies. In addition to the causes of stress and their effects, there are also other variables that can influence the relationship between stress and its effects, which are referred to as moderators. Gibson et al., (2012, p. 208-210) discuss three moderators that influence the relationship between stress and its effects, namely: personality, Type A behavior, and social support. 


\subsection{Emotional Intelligence (EI)}

Emotional intelligence involves the ability to accurately understand, assess and express emotions; the ability to access and / or generate feelings when they facilitate thinking; ability to understand emotions and emotional knowledge; and the ability to manage emotions for increased emotional and intellectual growth (Mayer \& Salovey, 1997). An important component in that definition is about emotion. In its most literal sense, the Oxford English Dictionary defines emotion as "any activity or upheaval of mind, feeling, lust, every great or overflowing mental state". I consider emotions to refer to their typical feelings and thoughts, a biological and psychological state, and a series of tendencies to act (Goleman, 2009, p. 409).

There is no agreement between experts in grouping emotions into large groups. So far, the emotional classification of things includes anger, sadness, fear, pleasure, love, surprise, annoyance, and shame (Goleman, 2009, p. 409-410). Emotions in their forms such as anger, happiness, and fear, as well as moods, preferences, and body condition, influence the way people think, make decisions, and do different tasks (Forgas \& Moylan, 1987; Mayer \& Bremer, 1985; Salovey \& Birnbaum, 1989 in Brackett et al., 2011). Negative emotions, especially chronic anger, anxiety, or feelings of failure, greatly disrupt work, distract attention from the task at hand (Goleman et al., 2002, p. 16).

Mayer et al., (2001) divided emotional intelligence into four skill areas. The four-branch model is a) perceiving emotions; b) using emotions to facilitate facilitating thought with emotion); c) understanding emotions (understanding emotions); and d) managing emotions in ways that enhance self-growth and social relations (managing emotion).

Goleman et al., (2004) states that the main task of a leader is how he can move collective emotions in a positive direction and get rid of the "haze" formed by toxic emotions. To be able to portray the main task needed by the leader with emotional intelligence with which he can harmonize with the feelings of people and move their feelings toward positive emotions. Furthermore Goleman et al., (2004) gave rise to four domains of emotional intelligence consisting of selfawareness, self-management, social awareness, and relationship management with eighteen competencies.

\subsection{Leadership Style}

Research on leadership has given rise to various leadership models. Among the most important are models that identify three types of leadership, namely transformational leadership, transactional and laissez-faire (Bass, 1997). Goleman et al., (2004) offer a classification of leadership styles that are typically associated with emotional intelligence, namely: visionary, mentor, affiliative, democratic, speed and command determinant. Although there are various types of leadership styles, each premise is how leaders interact, empower, and motivate the people they lead (Bakotic, 2008 in Leigh, 2012).

In transformational leadership, leaders change followers' needs, values, preferences and aspirations from selfinterest to collective interests. Furthermore, they cause followers to be very committed to the mission of the leader, to make personal sacrifices that are significant for the sake of the mission, and to do above and beyond the call of duty (Shamir et al., 1993). Transformational leaders encourage and inspire their supporters and create a healthy environment in the workplace by encouraging employees to ask questions, think about their jobs and work, find solutions to problems in the workplace, learn to create different opportunities and encourage and appreciate innovative ideas (Jha, 2014). In transactional leadership, leaders use carrots (awards) or sticks (punishment), as instrumental in achieving followers' goals (Bass 1997). Laissez-faire leadership consists of non-leadership or avoidance of leadership responsibilities. This type of leader fails to meet the requests of help from his followers, and refuses to convey their views on important issues (Bass, 1997). In transformational leadership, leaders change followers' needs, values, preferences and aspirations from selfinterest to collective interests. Furthermore, they cause followers to be very committed to the mission of the leader, to make personal sacrifices that are significant for the sake of the mission, and to do above and beyond the call of duty (Shamir et al., 1993). Transformational leaders encourage and inspire their supporters and create a healthy environment in the workplace by encouraging employees to ask questions, think about their jobs and work, find solutions to problems in the workplace, learn to create different opportunities and encourage and appreciate innovative ideas (Jha, 2014). In transactional leadership, leaders use carrots (awards) or sticks (punishment), as instrumental in achieving followers' goals (Bass 1997). Laissez-faire leadership consists of non-leadership or avoidance of leadership responsibilities. This type of leader fails to meet the requests of help from his followers, and refuses to convey their views on important issues (Bass, 1997).

\subsection{Conceptual Framework and Hypothesis}

In many studies work stress has a significant positive effect on deviant workplace behavior (Martin et al., 1996; Silva \& Ranasinghe, 2017; Raza et al., 2017; Salami, 2010; Omar et al., 2011; Pitariu \& Budean, 2015 ) Emotional intelligence has a significant negative effect on deviant workplace behavior found in Petrides et al. (2004), Brackett et al., (2004) and Martin (2014). Leadership as a moderator variable is supported by many studies. For example, Saidon et al., (2013) study of 669 employees in large electrical and electronic manufacturing companies in Malaysia, found that transformational leadership styles moderate the relationship between inactivity of moral self-regulation and interpersonal deviations. Syrek et al. (2013) study with the participation of 262 employees from seven information technology organizations in Germany, concluded that transformational leadership moderated the relationship between time pressure and employee fatigue. Yao et al., (2014) investigating 347 employees from 20 different places from industries such as manufacturing, construction, finance and insurance, transportation, and wholesale and retail industries, found that transactional leadership strengthened the effect of work stress on employee negative behavior. Whereas transformational leadership has a negative influence on the relationship between work stress and negative employee behavior.

The conseptual framework of this research can be described as follows: 


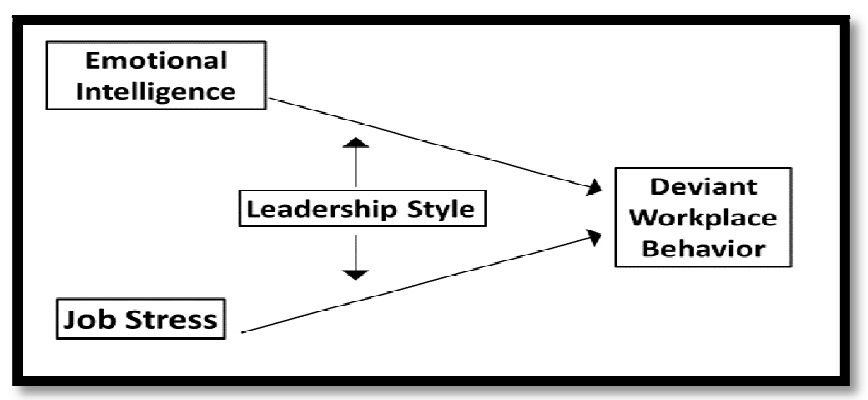

Figure 1: Theoretical Framework

- H1: It is suspected that there is a positive effect of work stress on employees' deviant workplace behavior

- H2: It is suspected that there is a negative influence of emotional intelligence on employees' deviant wokplace behavior

- H3: It is assumed that there is an influence of leadership style on the relationship between work stress and deviant workplace behavior of employees

- H4: It is assumed that there is an influence of leadership style on the relationship between emotional intelligence and deviant workplace behavior of employees.

\section{Research Methods}

\subsection{Research Design, Sampling and Data Collection}

This research is a study that aims to describe employee perceptions of emotional intelligence and work stress and prove the influence of emotional intelligence and work stress on deviant workplace behavior and see the moderating influence of leadership style on the relationship between the two. The approach used in the analysis is a quantitative descriptive approach to describe emotional intelligence, work stress, deviant workplace behavior and leadership style based on employee perceptions and relational approaches to prove the moderating influence of leadership style on the relationship between emotional intelligence, work stress and deviant behavior in place work.

The population in this study were all Account Representatives in the scope of the Pratama Tax Service Offices in Magelang, Temanggung and Klaten. The total number of employees at KPP Pratama Temanggung is 103 employees with an AR number of 43 employees. For KPP Pratama Magelang, the total number of employees is 109 employees with a total of 45 employees. While the total number of all Klaten Primary KPP employees is 119 with 43 AR numbers.

The data obtained are primary data by distributing questionnaires to Account Representatives that were used as respondents in this study.

\subsection{Research Instrument and Measures}

In this study deviant workplace behavior was measured by a measurement scale of workplace deviations developed by Bennett \& Robinson (2000) that represented behavior related to organizational deviant behavior (CWB-O) and interpersonal deviant behavior (CWB-I). Two scales were developed: a 12-item scale of organizational deviation and a 7-item scale of interpersonal deviation.

Stress levels were assessed using the Depression questionnaire, anxiety, stress scale 42 (DASS 42) issued by the Australian Psychology Foundation. DASS is a set of three self-report scales designed to measure negative emotional states of depression, anxiety and stress.

Emotional Intelligence is measured using the ECI-2 (The Emotional Competency Inventory) method developed by Daniel Goleman and Richard Boyatzis. ECI-2 shows the validity and reliability that can be accepted in various studies. It measures what should be measured, and measures it consistently. People who carry out the study thus feel it completes the existing emotional intelligence test (Boyatzis, Hay Group, 2011).

Bass \& Rigio (2006) stated that research in leadership, especially transformational leadership, had improved through the development of the Multifactor Leadership Questionnaire (MLQ). The Multifactor Leadership Questionnaire is a widely accepted measurement tool for assessing the constructs of transformational leadership, as well as transactional leadership and laissez-faire leadership developed by Bass \& Avolio in 2004. MLQ has been widely translated into Spanish, German, Indonesian, Swedish, Turkish, Arabic, Korean, and Hebrew (Lucey, 2017). 


\section{Result}

\subsection{Descriptive Statistics}

\begin{tabular}{|c|c|c|}
\hline Age & Frequency & Percentage (\%) \\
\hline$<25$ years & 1 & 0,8 \\
\hline $26-35$ years & 55 & 44,4 \\
\hline $36-45$ years & 56 & 45,2 \\
\hline$>46$ years & 12 & 9,7 \\
\hline Total & 124 & 100,0 \\
\hline Gender & & 67,7 \\
\hline Male & 84 & 32,3 \\
\hline Female & 40 & 100,0 \\
\hline Total & 124 & \\
\hline Education / Qualification & & 21,8 \\
\hline Diploma (I, II, III) & 27 & 63,7 \\
\hline Bachelor & 79 & 14,5 \\
\hline Masters & 18 & 100,0 \\
\hline Total & 124 & \\
\hline
\end{tabular}

Tabel 1: Characteristics of Respondents

From table 1 it can be described that the majority of employees aged between 26 -35 years (44.4\%) and between 36 - 45 years (45.2\%). Most of the respondents were male with a total of 84 people (67.7\%) and female respondents as many as 40 people (32.3\%). Based on education, the majority of respondents had a Bachelor degree (63.7\%), the rest were educated Diploma (I, II, III) (21.8\%) and masters as much as $14.5 \%$.

\begin{tabular}{|c|c|c|c|c|}
\hline & $\begin{array}{c}\text { Job Stress } \\
\left(\mathbf{X}_{\mathbf{1}}\right)\end{array}$ & $\begin{array}{c}\mathbf{E I} \\
\left(\mathbf{X}_{\mathbf{2}}\right)\end{array}$ & $\begin{array}{c}\text { Leadership } \\
\text { Style (Z) }\end{array}$ & DWB (Y) \\
\hline Mean & 1,950 & 3,827 & 3,924 & 1,378 \\
\hline Std. Dev. & 0,559 & 0,553 & 0,605 & 0,262 \\
\hline
\end{tabular}

Table 2: Mean and Standard Deviation of Research Variables Source: Data Processed, 2019

Based on the table above it can be stated that the mean work stress of employees is low (mean $=1,950$ on a scale of 1 to 5). The level of emotional intelligence of employees is generally high (mean =3.827). The practice of leadership style is high (mean $=3,924)$. While the deviant workplace behavior is low (mean $=1,378)$.

2. Test of Research Instruments

Validity and Reliability

\begin{tabular}{|c|c|c|c|}
\hline Variable & N of item & $\begin{array}{c}\text { Corrected Item- } \\
\text { Total Correlation }\end{array}$ & $\begin{array}{c}\text { Cronbach's } \\
\text { Alpha }\end{array}$ \\
\hline Job Stress & 20 & $0,448-0,752$ & 0,929 \\
\hline EI & 35 & $0,431-0,767$ & 0,954 \\
\hline Leadership Style & 35 & $0,436-0,867$ & 0,968 \\
\hline DWB & 23 & $0,350-0,597$ & 0,877 \\
\hline
\end{tabular}

Tabel 3: Validity and Reliability Result

Source: Data Processed, 2019

Based on testing the validity obtained the value of the correlation coefficient above 0.30 which indicates that the research instrument is valid. Based on reliability testing it was found that the research instrument was reliable with Cronbach's Alpha $>0.60$. Normality and Multicollinearity

\begin{tabular}{|c|c|c|c|c|}
\hline Variable & \multirow{2}{*}{ KS-Z } & \multirow{2}{*}{ Sig } & \multicolumn{2}{|c|}{ Collinearity Statistics } \\
\cline { 4 - 5 } & & & Tolerance & VIF \\
\hline Job Stress $\left(\mathrm{X}_{1}\right)$ & 0,065 & 0,200 & 0,964 & 1,038 \\
\hline EI $\left(\mathrm{X}_{2}\right)$ & 0,061 & 0,200 & 0,946 & 1,057 \\
\hline Leadership Style & 0,070 & 0,200 & 0,957 & 1,045 \\
\hline DWB & 0,077 & 0,070 & & \\
\hline
\end{tabular}

Tabel 4: Normality Test (One-Sample Kolmogorov-Smirnov Test)

Source: Data Processed, 2019 
Based on the table above it can be concluded that the variables are normally distributed with a value of sig>0.05. The regression model does not occur multicollinearity because the value of Tolerance $>0.1$ and VIF value $<10$. Heteroscedasticity Test

\begin{tabular}{|c|c|c|}
\hline Variable & Sig & $\begin{array}{c}\text { Correlation } \\
\text { Coefficient }\end{array}$ \\
\hline Job Stress $\left(\mathrm{X}_{1}\right)$ & 0,637 & 0,043 \\
\hline EI $\left(\mathrm{X}_{2}\right)$ & 0,602 & $-0,047$ \\
\hline Leadership Style $(\mathrm{Z})$ & 0,822 & $-0,020$ \\
\hline Job Stress*Leadership Style $\left(\mathrm{X}_{1} . \mathrm{Z}\right)$ & 0,936 & $-0,007$ \\
\hline EI*Leadership Style $\left(\mathrm{X}_{2} \cdot \mathrm{Z}\right)$ & 0,717 & $-0,033$ \\
\hline
\end{tabular}

Tabel 5: Heteroscedasticity Test Results

There is no problem of heteroscedasticity in the regression model because sig $>0.05$, which means that the respondents in this study are classified as homogeneous.

\section{Multiple Linear Regression Analysis}

\subsection{Multiple Linear Regression Analysis}

\begin{tabular}{|c|c|c|c|c|}
\hline $\begin{array}{c}\text { Independent } \\
\text { Variable }\end{array}$ & Coefficient & Sig t & (R') & Sig F \\
\hline (Constant) & 34,497 & 0.000 & 0,181 & 0,000 \\
\cline { 1 - 2 } Job Stress $\left(\mathrm{X}_{1}\right)$ & 0,205 & 0,000 & & \\
\hline EI $\left(\mathrm{X}_{2}\right)$ & $-0,081$ & 0,002 & & \\
\hline
\end{tabular}

Table 6: Result of Multiple Linear Regression Analysis Dependent Variable: Y Deviant Workplace Behavior (DWB)

Source: Data Processed, 2019

Based on the data presented in Table 4.21 it can be concluded that individually work stress variables ( sig $\mathrm{t}=$ 0,000 ), and emotional intelligence (sig $t=0,002$ ) influence the deviant behavior in the workplace. The coefficient of determination (R2) the influence of work stress variables, and emotional intelligence on deviant workplace behavior obtained a number of 0.181 or $18.1 \%$. These results indicate that $18.1 \%$ of DWB is explained by work stress variables and emotional intelligence together while the remaining $81.9 \%$ is explained by other causes outside of the two variables. Based on F count with a significance of 0,000 it can be concluded that work stress and emotional intelligence simultaneously influence DWB.

Based on the table above, it can be formulated with multiple regression equations as follows: $\mathrm{Y}=34,497+0,205 \mathrm{X} 1-0,081 \mathrm{X} 2$

The number 34,497 is intercept. The number 0.205 in the above equation is the coefficient slope of Job Stress (X1). The positive coefficient slope number (+0.205) shows a positive influence on each change in work stress level (X1) towards $\mathrm{Y}$ (DWB). Each increase in X1 will increase $\mathrm{Y}$ and vice versa every decrease in X1 will decrease $\mathrm{Y}$. The number 0.081 in the equation above is the coefficient slope of EI (X2). The negative coefficient slope number shows the negative effect of each change in X2 on Y. Every increase in level X2 (EI) will cause a decrease in Y (DWB) and vice versa.

\subsection{Analysis of the Moderating Variables}

\begin{tabular}{|c|c|c|c|c|}
\hline Independent Variable & Coefficient & Sigi t & $\left(\mathbf{R}^{2}\right)$ & Sig F \\
\hline (constant) & $-3,526$ & 0,821 & \multirow[t]{6}{*}{0,533} & \multirow[t]{6}{*}{0,000} \\
\hline Job Stress $\left(\mathrm{X}_{1}\right)$ & 1,755 & 0,000 & & \\
\hline $\mathrm{EI}\left(\mathrm{X}_{2}\right)$ & $-0,367$ & 0,001 & & \\
\hline Leadership Style $(\mathrm{Z})$ & 0,302 & 0,016 & & \\
\hline Job Stress * Leadership Style ( $\left.\mathrm{X}_{1} . \mathrm{Z}\right)$ & $-0,012$ & 0,000 & & \\
\hline EI* Leadership Style $\left(\mathrm{X}_{2} . \mathrm{Z}\right)$ & 0,002 & 0,015 & & \\
\hline
\end{tabular}

Table 7: Results of Multiple Linear Regression Analysis with Moderating Variables

Dependent Variable: Y Deviant Workplace Behavior

Source: Data Processed, 2019

Based on the data processing presented in Table 4.22 it is known that the significance of $t$ for the moderating variable (X1.Z) is 0,000 which means significant at $\alpha=5 \%$. These results indicate that the leadership style moderates the relationship between work stress and DWB. It is known that the regression coefficient of work stress variable (X1) is 1.755 and the moderating variable is the interaction variable between work stress and leadership style (X1.Z) is -0.012. If there is no moderating leadership style variable, the magnitude of the effect of work stress on deviant behavior is 1.755. However, if there is a leadership style variable as a moderating variable, the effect of work stress on DWB has decreased 
because the coefficient value of the interaction variable between work stress and leadership style (X1.Z) is negative. Mathematically the magnitude of the influence of work stress variables (X1) with the leadership style moderating variable is $1.743(1.755-0.012)$ towards DWB (Y). Then it can be stated that leadership style is a moderating variable on the relationship between work stress and DWB.

While the significance of $t$ for the leadership style moderating variable on the relationship between emotional intelligence and DWB (X2.Z) is 0.015 which means significant. These results indicate that the leadership style moderates the relationship between EI and DWB. The magnitude of the regression coefficient for the EI variable (X2) is equal to 0.376 and for the moderating variable namely the interaction variable between EI and leadership style (X2.Z) is 0.002 . If there is no moderating leadership style variable, the magnitude of the influence of EI on DWB is -0.376 . But if there is a leadership style variable as a moderating variable, the influence of EI on DWB increases because the coefficient value of the interaction variable between EI and leadership style (X2.Z) is positive (+0.002). Mathematically the magnitude of the influence of the EI variable (X2) with the leadership style moderating variable is at $-0,365(-0,367+0,002)$ towards DWB (Y). So that it can be stated that leadership style is a moderating variable on the relationship between EI and DWB.

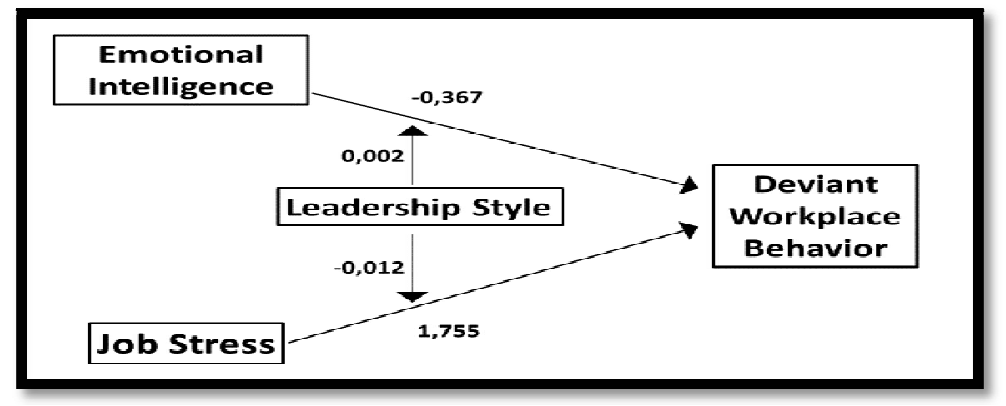

Figure 2: Framework for Data Results

\section{Discussion}

- Stress is a reaction to situations or events that place excessive psychological and / or physical demands on someone (Gibson et al., 2012). Job pressure caused by these conditions has the potential to cause work stress which can have implications for DWB. Employee stress levels were found to be relatively moderate ( $m e a n=1,950$ on a scale of 1 to 5). Although the level of deviant workplace behavior from the results of the study is very low (mean $=1.378$, on a scale of 1 to 5 ) but there is the effect of work stress on DWB as indicated by the t-count test of 8.948 with a significance of $0,000(\varangle 0,05)$ and the regression coefficient value is 1.755 (positive). Such conditions indicate that the increasing work stress of employees will increase the frequency of DWB. So the hypothesis that there is a positive effect of work stress on DWB of employees is accepted.

- The results of the questionnaire data obtained from respondents indicate that on average the respondents have high EI with a mean of 3.827 on a scale of 1-5. The higher a person's EI, the more he can control negative deviant behavior in his workplace. The negative effect of EI on deviant behavior of employees in the workplace is indicated by the results of the t-test statistic of $-3,564$ with a significance of $0,000(\varangle 0,05)$ and a regression coefficient of $-0,367$ (negative). The higher the EI of employees, the less the frequency of DWB. Thus the hypothesis that there is a negative influence of EI on DWB of employees is accepted.

- The results of data processing on the leadership style practiced by leadership shows a high frequency with a mean of 3.924 on a scale of 1 to 5 . Intensive interaction between subordinates and superiors in this case section head (echelon 4) is conditioned by a load situation high work. The high workload felt by employees often requires support and solution direction from their superiors when faced with severe problems. Based on the results of data processing, it was found that there was a negative moderating effect of leadership style on the relationship between work stress and DWB. This is indicated by the results of the t-test statistic of - 7,894 with a significance of $0,000(\varangle 0,05)$ and a regression coefficient of $-0,012$ (negative). The more often applied leadership style will weaken the relationship between work stress and DWB. Thus the hypothesis that there is an influence of leadership style on the relationship between work stress and DWB of employees is accepted. Specifically, it was stated that the relationship between work stress and DWB was weaker for employees who reported a higher level of leadership style.

- Results of data processing indicate that there is a moderating influence of leadership style on the relationship between EI and DWB. This is indicated by the results of the t-test statistic of 2.459 with a significance of 0.015 $(\varangle 0.05)$ and a regression coefficient of 0.002 . Positive coefficient value $(+0.002)$ indicates that the more often applied leadership style will weaken the negative relationship between EI and DWB. Thus the hypothesis that there is an influence of leadership style on the relationship between EI and DWB of employees is accepted.

\section{Conclusion}

- There is a positive and significant influence of employee work stress on deviant workplace behavior. The higher the level of work stress experienced by employees, the higher the frequency of deviant workplace behavior.

- There is a negative and significant influence of the level of emotional on deviant workplace behavior. The higher the level of emotional intelligence of employees, the less frequent the frequency of deviant workplace behavior. 
- There is a negative and significant influence of leadership style on the relationship between work stress and deviant workplace behavior. The higher the frequency of leadership style will weaken the relationship between work stress and deviant behavior in the workplace.

- There is a positive and significant influence of leadership style on the relationship between emotional intelligence and deviant workplace behavior. The higher the frequency of leadership style will weaken the negative relationship between emotional intelligence and deviant behavior in the workplace.

\section{Managerial Implementation}

There are other variables that might explain deviant behavior in an employee's workplace. Subsequent research with different variables and different loci will enrich understanding of deviant behavior in the workplace. In addition, research on how transformational and transactional styles separately affect the dependent variable will better explain and complement this research.

\section{References}

i. Alias, M., Rasdi, R. M., Ismail, M., \& Samah., B. A. (2013). Predictors of workplace deviant behaviour: HRD agenda for Malaysian support personnel. European Journal of Training and Development. Vol. 37 No. 2, pp. 161-182.

ii. Appelbaum, S. H., Iaconi, G. D., \& Matousek, A. (2007). Positive and negative deviant workplace behaviors: causes, impacts, and solutions. Corporate Governance. Vol. 7 No. 5, pp. 586-598.

iii. Bass, B. M. (1997). Does the Transactional-Transformational Leadership Paradigm Transcend Organizational and National Boundaries? American Psychological Association, Inc. Vol. 52, No. 2.130-139.

iv. Bolton, L. R., Becker, L. K., \& Barbe, L. K. (2010). Big Five trait predictors of differential counterproductive work behavior dimensions. Personality and Individual Differences 49 537-541.

v. Boyatzis, R. E. (2011). The Creation of the Emotional and Social Competency Inventory (ESCI). Hay Group.

vi. Brackett, M. A., Rivers, S. E., \& Salovey, P. (2011). Emotional Intelligence: Implications for Personal, Social, Academic, and Workplace Success. Social and Personality Psychology Compass 5/ 1 : 88-103.

vii. Brackett, M. A., Mayer, J. D., \& Warner, R. M. (2004). Emotional intelligence and its relation to everyday behaviour. Personality and Individual Differences 36 1387-1402

viii. Douglas, S. C., \& Martinko, M. J. (2001). Exploring the Role of Individual Differences in the Prediction of Workplace Aggression. Journal of Applied Psychology, Vol. 86, No. 4, 547-559.

ix. Fox, S., Spector, P. E., \& Miles, D. (2001). Counterproductive Work Behavior (CWB) in Response to Job Stressors and Organizational Justice: Some Mediator and Moderator Tests for Autonomy and Emotions. Journal of Vocational Behavior 59, 291-309.

x. Galperin, B. L. (2002). Determinants of deviance in the workplace: an empirical examination in Canada and Mexico. Concordia University. Montreal.

xi. Gibson, J. L., Ivancevich, J. M., Donnelly, J. H. Jr., \& Konopaske, R. (2012). Organizations : Behavior, Structure, Processes. Fourteenth Edition. McGraw-Hill Companies, Inc., 1221 Avenue of the Americas, New York, NY, 10020.

xii. Goleman, D. (2009). Emotional Intelligence: Mengapa EI Lebih Penting daripada IQ. Terjemahan: T. Hermaya. Gramedia, Jakarta.

xiii. Goleman, D., Boyatzis, R., \& McKee, A. (2002). The New Leaders. Transforming The Art Of Leadership Into The Science Of Results. Harvard Business School Press.

xiv. Goleman, D., Boyatzis, R., \& McKee, A. (2004). Primal Leadership - Kepemimpinan Berdasarkan Kecerdasan Emosi. Alih Bahasa: Susi Purwoko. PT Gramedia Pustaka Utama, Jakarta.

xv. Golparvar, M., Kamkar, M., \& Javadian, Z. (2012). Moderating Effects of Job Stress in Emotional Exhaustion and Feeling of Energy Relationships with Positive and Negative Behaviors: Job Stress Multiple Functions Approach. International Journal of Psychological Studies; Vol. 4, No. 4;

xvi. Gupta, N., \& Beehr, T. A. (1979). Job Stress and Employee Behaviors. Organizational Behavior And Human. 23, 373387

xvii. Hater, J. J., \& Bass,B. M. (1988). Supervisor' Evaluations and Subordinates' Perceptions of Transformational and Transactional Leadership. Journal of Applied Psychology, Vol. 73, No. 4, 695-702.

xviii. Hay Group. (2011). Emotional and social competency inventory (ESCI). A user guide for accredited practitioners. www.haygroup.com.

xix. Jha, Sumi. (2014). Transformational Leadership And Psychological Empowerment. Determinants of Organizational Citizenship Behavior. South Asian Journal of Global Business Research. Vol. 3 No. 1, pp. 18-35.

xx. Lambert, E. G., Hogan, N. L., \& Griffin, M. L. (2007). The impact of distributive and procedural justice on correctional staff job stress, job satisfaction, and organizational commitment. Journal of Criminal Justice, 35, 644656.

xxi. Lazarus, R. S., \& Launier, R. (1978). Stress-Related Transactions between Person and Environment. Perspectives in interactional psychology, Vol. 1 No. 1, pp. 287-327.

xxii. Leigh, C. (2012). Examining the Relationship between Emotional Intelligence and Leadership Styles of U.S. Navy Senior Enlisted Leaders. ProQuest LLC 789 East Eisenhower Parkway.

xxiii. Lucey, P. A. (2017). Leadership Style and Organizational Citizenship Behavior in Community-Based Mental Health Facilities. Walden University ScholarWorks.

xxiv. Luthans, F. (2011). Organizational Behavior : An Evidence-Based Approach. Twelfth Edition. McGraw-Hill Irwin. 
xxv. Martin, D. M. (2014). Emotional Intelligence And Workplace Aggression: A Meta-Analysis. Romanian Journal Experimental Applied Psychology. Vol. 5, Issue 2, 27-36.

xxvi. Martin, J. K., Roman, P. M., \& Blum, T. C. (1996). Job Stress, Drinking Networks, And Social Support At Work: A Comprehensive Model Of Employees' Problem Drinking Behaviors. The Sociological Quarterly, Volume 37, Number 4, pages 579-599.

xxvii. Mayer, J. D. \& Salovey, P. (1997). What is emotional intelligence? In: Salovey, P., Sluyter, D. (Eds), Emotional Development and Emotional Intelligence: Educational Implications. Basic Books, New York, NY, pp. 3-34.

xxviii. Mayer, J. D., Salovey, P., Caruso, D. R., \& Sitarenios, G. (2001). Emotional Intelligence as a Standard Intelligence. American Psychological Association, Inc. Vol. 1, No. 3, 232-242.

xxix. Omar, F., Halim, F. W., Zamani, Z. A., Farhadi, H., Nasir, R., \& Khairudin, R. (2011). Stress and job satisfaction as antecedents of workplace deviant behavior. World Applied Sciences Journal 12 (Special Issue of Social and Psychoogical Sciences for Human Development): 46-51, ISSN 1818-4952.

xxx. Petrides, K.V., Frederickson, N., \& Furnham, A. (2004). The role of trait emotional intelligence in academic performance and deviant behavior at school. Personality and Individual Differences 36 277-293.

xxxi. Pieterse, A.cN., Knippenberg, D. V., Schippers, M. and Stam, D. (2010). Transformational and transactional leadership and innovative behavior: the moderating role of psychological empowerment. Journal of Organizational Behavior, Vol. 31 No. 4, pp. 609 - 623.

xxxii. Pitariu, H. D., \& Budean, A. (2015). The Impact of Occupational Stress on Job Satisfaction and Counterproductive Work Behaviour. Psihologia Resurselor Umane.

xxxiii. Raza, S., Hussain, M. S., Azeem, M., Ansari, N., \& Aziz, K. (2017). Workload, Work Stress, Role Conflict, and Workplace Deviant Behaviour in Banks: an Empirical Analysis. European Online Journal of Natural and Social Sciences. Vol.6, No 4 pp. 701-707.

xxxiv. Robinson, S. L., \& Bennett, R. J. (1995). A Typology Of Deviant Workplace Behaviors: A Multidimensional Scaling Study. Academy of Management Journal. Vol. 38, No. 2, 555-572.

xxxv. Robinson, S. L., \& O'Leary-Kelly, A. M. (1998). Monkey See, Monkey Do: The Influence Of Work Groups On The Antisocial Behavior Of Employees. Academy of Management fournal, Vol. 41, No. 6, 658-672.

xxxvi. Saidon, I. M., Galbreath, J., \& Whiteley, A. (2013). Moderating Role of Transformational Leadership on the Relationship between Moral Disengagement and Workplace Deviance. Australian Journal of Basic and Applied Sciences, 7(8): 706-719. ISSN 1991-8178

xxxvii. Salami, S. O. (2010). Job Stress and Counterproductive Work Behaviour: Negative Affectivity as a Moderator. The Social Sciences 5 (6): 486-492. ISSN: 1818-5800

xxxviii. Shamir, B., House, R. J. \& Arthur, M. B. (1993). The Motivation Effects Of Charismatic Leadership: A Self-Concept Based Theory. Organization Science Vol. 4 Np. 4.

xxxix. Silva, H. M. S. V., \& Ranasinghe, R. M. I. D. (2017). The Impact of Job Stress on Deviant Workplace Behaviour: A Study of Operational Level Employees of Comfort Apparel Solutions Company in Sri Lanka. International Journal of Human Resource Studies. Vol. 7, No. 1.

xl. Spreitzer, G. M., \& Sonenshein, S. (2004). Toward the construct definition of positive deviance. American Behavioral Scientist, Vol. 47 No. 6, pp. 828-47

xli. Stamper, R., Liu, K., Hafkamp, M., \& Ades, Y. (2000). Understanding the Roles of Signs and Norms in OrganisationsA semiotic approach to information systems design. Journal of Behaviour \& Information Technology, vol. 19 (1), pp 15-27.

xlii. Syrek, C. J., Apostel, E., \& Antoni, C. H. (2013). Stress in Highly Demanding IT Jobs: Transformational Leadership Moderates the Impact of Time Pressure on Exhaustion and Work-Life Balance. Journal of Occupational Health Psychology. Vol. 18, No. 3, 252-261.

xliii. Vardi, Y., \& Wiener, Y. (1996). Misbehavior in Organizations: A Motivational Framework. Organizational Science, Vol. 7, No. 2.

xliv. Yao, Y. H., \& Fan, Y. Y., Guo, Y. X., Li, Y. (2014). Leadership, work stress and employee behavior. Chinese Management Studies. Vol. 8 No. 1.pp. 109-126. 